\title{
NATURAL AND ANTHROPOGENIC EFFECTS ON SALT MARSH OVER FIVE DECADES IN THE PATOS LAGOON (SOUTHERN BRAZIL)
}

\author{
Juliano César Marangoni* and César Serra Bonifácio Costa
}

Instituto de Oceanografia - FURG

(Caixa Postal 474, 96201-900 Rio Grande, RS, Brasil)

*julianomarangoni@ pop.com.br

Salt marshes constitute major coastal ecosystems in the intertidal zones in temperate regions covered with halophytic plants. In southern Brazil, salt marshes occupy $70 \mathrm{~km}^{2}$ of the Patos Lagoon estuary (COSTA et al., 1997), accounting for $93 \%$ of the area covered by these environments in the State of the Rio Grande do Sul (COIMBRA; COSTA, 2006). The salt marshes in the area of the Patos Lagoon estuary have been lost and degraded, since early in the nineteenth century, by urban, industrial and port expansion (COSTA et al., 1997; COSTA; MARANGONI 2000; SEELIGER; COSTA 1997; 2003). Furthermore, local losses of salt marshes owing to erosion have been observed (SEELIGER; COSTA, 1997; COSTA and MARANGONI, 2000; MARANGONI, 2003; COSTA et al., 2005), though not quantified. Ongoing environmental changes on a regional scale may intensify local hydrology, such as mean sea level rise (4 mm/year; MESQUITA, 2003) and increment of freshwater discharge in the catchment area of the Patos Lagoon (MARENGO, 2006). The goals of this study were to quantify the gains and losses of the different salt marsh units on the margin of the Patos Lagoon estuary over the last 53 years (1947-1975-2000) and to identify the natural process and/or anthropogenic effect responsible for these changes.

This study was carried out in the coastal municipalities of Rio Grande and São José do Norte, located on the Patos Lagoon estuary, southern Brazil $\left(31^{\circ} 50^{\prime}-32^{\circ} 09^{\prime} \mathrm{S} ; 52^{\circ} 00^{\prime}-52^{\circ} 15^{\prime} \mathrm{W}\right)$ (Fig. 1). There are 24 distinct salt marsh units on the Patos Lagoon estuary, according to their geographical distribution

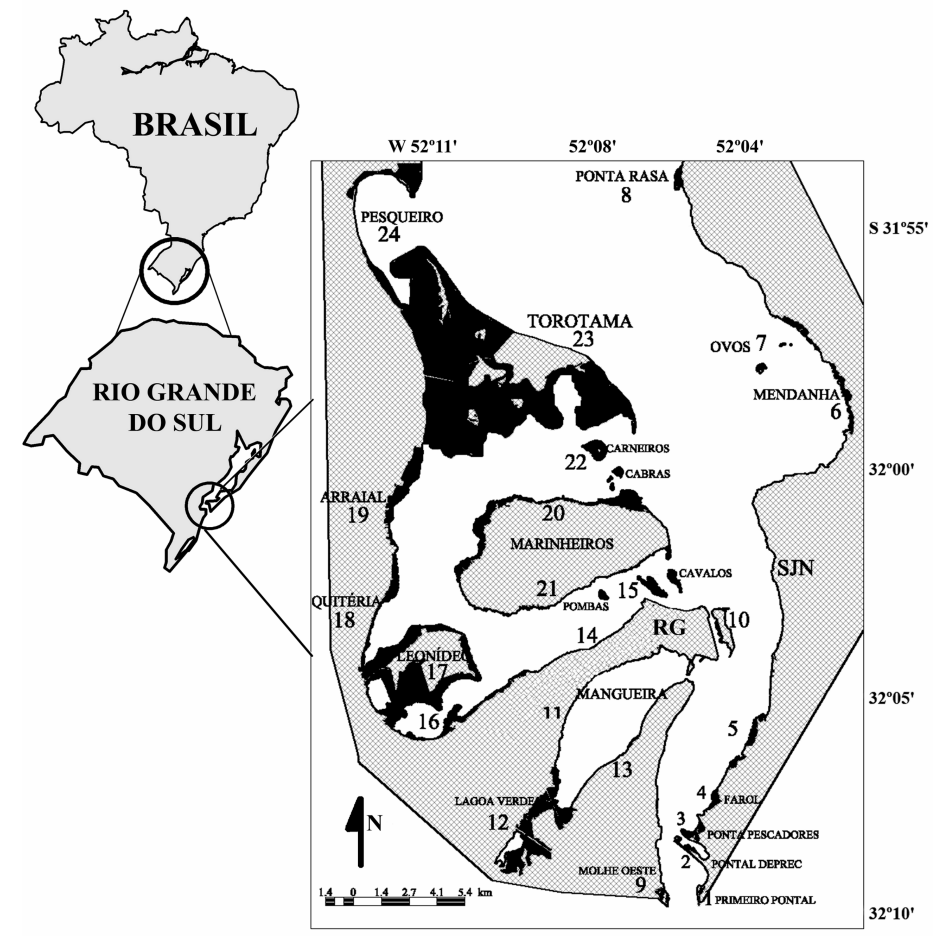

Fig. 1. Patos Lagoon estuary (RS-Brazil) with location of 24 salt marsh units (black areas) in São José do Norte (east margin) and Rio Grande (west margin). 
and physiography (COSTA et al., 1997; NOGUEIRA; COSTA, 2003). The mapping of these units was accomplished using GIS analysis of aerial photos of the years 1947 (B\&W - scale 1:40,000), 1975 (B\&W 1:20,000) and 2000 (RGB digital with resolution of 1 meter per pixel - mpp). To solve some problems in the aerial cover of 2000 (about $10 \%$ of the total area), $\mathrm{B} \& \mathrm{~W}$ photos of $1996(1: 60,000)$ and satellite images LANDSAT 7 ETM (2002) were used. Not all the estuarine margin is covered by salt marshes therefore, in order to verify whether the land gain or loss was affecting only the salt marshes or the entire estuarine margin (e.g. sandy fields, fringe woods), the variation in the area $\left(\mathrm{km}^{2}\right)$ of the estuarine margin over the period of 19 years was also assessed by the GIS photointerpretation of satellite images of Landsat 5 TM (1987), Landsat 7 ETM (2002) and Landsat 7 ETM (2006). To quantify any variation in the estuarine margin a polygon was drawn for each LANDSAT image with the same points on the land as vertices, thus any displacement of water-continent line was taken as variation (increase or decrease) in the area of the margin. All images (B\&W, RGB and Satellite images) were processed and analyzed using the GIS Spring 4.3.3 free software developed by the Brazilian Space Agency (INPE) (CÂMARA et al., 1996) with a final resolution of $1 \mathrm{mpp}$ (meter per pixel) for $\mathrm{B} \& \mathrm{~W}$ and $\mathrm{RGB}$ images and $30 \mathrm{mpp}$ for Satellite images. The accuracy of the measurements made on the aerial photos (2000, 1975 and 1947) was evaluated by comparing five (5) linear measurements of selected objects clearly identified in 2000 with the corresponding measurements made on the previous images. The measurements demonstrated a mean linear error of $0.51 \%$ and a mean area error of $1.07 \%$. Gains or losses in salt marsh area from aerial photointerpretation (1947-1975-2000) were considered when they were greater than the measurement error (at least twice the value of the mean area error), corresponding to a variation in area equal to or greater than $\pm 0.08 \%$ per year, to minimize possible mistakes caused by GIS procedures.

The salt marshes of Rio Grande county (RG) accounted, in 2000 , for $95.7 \%\left(66.85 \mathrm{~km}^{2}\right)$ of the total salt marsh area $\left(69.84 \mathrm{~km}^{2}\right)$ of the Patos Lagoon estuary and overall the marshes had decreased their area at a rate of $-0.03 \%$ per year over the first period of study (28 years; 1947-1975) but remained stable over the last 25 years $(+0.005 \%)$. During the first 28 year time span (1947-1975), 50\% of RG salt marsh units (8 units) suffered reduction markedly in the units 9, 11, 15 and 22, spread along the estuary (Table 1). In this period, erosive process and anthropogenic activity

Table 1. Changes in salt marsh areas (\%) in São José do Norte and Rio Grande between periods 1947-1975 and 1975-2000. The salt marsh areas $\left(\mathrm{km}^{2}\right)$ in the year of 2000 are also shown. Variations above $\pm 0.50 \%$ per year are highlighted with positive values in gray cells and negative values in bold.

\begin{tabular}{|c|c|c|c|c|c|}
\hline & & Salt marsh Unit & $\begin{array}{c}\text { Area Variation } \\
\text { per year }(\%) \\
1947-1975\end{array}$ & $\begin{array}{c}\text { Area Variation } \\
\text { per year }(\%) \\
1975-2000\end{array}$ & $\begin{array}{c}\text { Total Area } \\
\left(\mathrm{km}^{2}\right) \\
2000\end{array}$ \\
\hline \multirow[t]{8}{*}{ SJN } & "201" & Primeiro Pontal & 5.19 & 43.09 & 0.06 \\
\hline & 02 & Pontal Deprec & 5.93 & 3.07 & 0.09 \\
\hline & 03 & Ponta dos Pescadores & -0.39 & -0.13 & 0.38 \\
\hline & 04 & Farol & -0.49 & -0.39 & 0.29 \\
\hline & 05 & SJN Sul & -0.21 & -0.18 & 0.66 \\
\hline & 06 & Mendanha & 0.06 & 0.06 & 1.05 \\
\hline & 07 & Ovos and Arvoredo Islands & & & \\
\hline & 08 & Ponta Rasa & $\begin{array}{l}-\mathbf{1 . 4 5} \\
-0.14\end{array}$ & $\begin{array}{l}-1.80 \\
-0.23\end{array}$ & $\begin{array}{l}0.14 \\
0.32\end{array}$ \\
\hline \multirow[t]{18}{*}{ Rio Grande } & 09 & Molhe Oeste & -1.12 & 1.68 & 0.16 \\
\hline & 10 & Terrapleno Island & 32.63 & 2.32 & 0.18 \\
\hline & 11 & Mangueira Norte & -1.77 & -0.14 & 0.56 \\
\hline & 12 & Lagoa Verde & -0.01 & -0.05 & 2.96 \\
\hline & 13 & Mangueira Sul & -0.07 & -0.05 & 0.81 \\
\hline & 14 & Rio Grande & -0.31 & -0.29 & 0.03 \\
\hline & 15 & Cavalos Island & -1.39 & -1.40 & 0.26 \\
\hline & 15 & Pólvora Island & -0.66 & -0.63 & 0.47 \\
\hline & 15 & Pombas Island & -0.85 & -0.96 & 0.12 \\
\hline & 16 & Justino & 0.04 & -0.01 & 1.23 \\
\hline & 17 & Leonídeo Island & 0.08 & 0.09 & 8.47 \\
\hline & 18 & Quitéria & 0.10 & 0.01 & 1.02 \\
\hline & 19 & Arraial & 0.04 & -0.13 & 2.08 \\
\hline & 20 & Marinheiros Norte Island & -0.06 & 0.01 & 3.14 \\
\hline & 21 & Marinheiros Sul Island & -0.30 & -0.45 & 0.70 \\
\hline & 22 & Carneiros/Cabras Islands & -0.76 & -1.16 & 0.86 \\
\hline & 23 & Torotama Island & 0.03 & 0.03 & 41.55 \\
\hline & 24 & Pesqueiro & -0.02 & 0.04 & 2.25 \\
\hline
\end{tabular}


(urban expansion) were responsible for $53.8 \%$ and $46.2 \%$ of the total losses of the salt marsh area $(-1.23$ $\mathrm{km}^{2}$ ), respectively (Table 2). The total gain in salt marsh area $\left(0.31 \mathrm{~km}^{2}\right)$ was due to natural (plant colonization; 66.9\%) and anthropogenic causes (disposal of dredged sediment and subsequent plant colonization; $33.1 \%$ ), respectively (Table 2 ). In the last 25 years (1975-2000), ten RG units suffered significant losses $\left(-0.52 \mathrm{~km}^{2}\right)$, lead by units 15 and 22 (Table 1) because of erosion ( $86.2 \%$ of losses) and anthropogenic activity (units 18 and 19; aquaculture ponds; $13.8 \%$ ) (Table 2). In this same period, 3 units gained in area $\left(0.30 \mathrm{~km}^{2}\right)$ (Tables 1 and 2) as a result of anthropogenic activity (units 9 and 10;37.1\% of total area) (plant colonization in sheltered areas due to the construction of rock groins and disposal of dredged sediment, respectively) and unit 17 by a natural process (plant colonization; 62.9\%). The salt marshes of São José do Norte county (SJN) account for only $4.3 \%\left(2.99 \mathrm{~km}^{2}\right)$ of the total and they had decreased their area at rates of $-0.21 \%$ and $-0.05 \%$ per year, in the first (1947-1975) and second (1975-2000) periods of study, respectively. Most of the salt marshes of SJN had lost area over the last 53 years $\left(-0.41 \mathrm{~km}^{2}\right)$ as a result of erosion, with marked stress on unit 7 (average rate of $-1.62 \%$ per year) (Tables 1 and 2). On the other hand, two marsh units (1 and 2) in southern SJN had increased their areas throughout the study period (mean $=14.3 \%$ per year) caused by plant colonization in new depositional areas (Tables 1 and 2). The RG estuarine margin and Leonídeo Island area increased at a mean rate of $0.005 \%$ and $0.06 \%$ per year, respectively, however, other RG islands facing the navigation channel northward (Carneiros, Cabras, Baicurus and Zumbi) and southward of Marinheiros Island (Cavalos, Pólvora and Pombas) showed reductions in their sizes by natural erosive processes (Table 3). Similarly to most of the salt marsh units, the estuarine margin of SJN suffered losses in area throughout the last two decades with a cumulative value of $-1.03 \mathrm{~km}^{2}$ and a rate of $-0.04 \%$ per year. Three SJN estuarine islands had reduced their areas at an overall average rate of $-1.80 \%$ per year (Table 3 ).

Negative Effects - The erosive process on the estuarine margin and salt marshes in SJN seems to be related to wave erosion generated by strong winds from SW to NW, responsible for a piling up of water on the east margin of the estuarine inlet and blowing during $13.5 \%(\mathrm{SW})$ and $3.7 \%(\mathrm{NW})$ of the year at a speed of 2-8 m/s (GAFRÉE, 1927 apud SILVA, 1941; VIEIRA and RANGEL, 1988; DHN, 1990; TOMAZELLI, 1993; BRAGA; KRUSCHE, 2000). SW-NW winds are related to the passage of cold fronts associated with the migratory Polar Anticyclones, with a periodicity of 6-7 days during fall and winter in southern Brazil (HASENACK;
FERRARO, 1989; NIMER, 1989; STECH; LORENZZETTI, 1992; TOLDO et al., 2003). Probably the most important cause of erosion on the western margin of the estuary is caused by waves from piling up of water due to the dominant winds from NE-SE that blow, respectively, for $22.3 \%$ and $7.4 \%$ of the time (GAFRÉE, 1927 apud SILVA, 1941; VIEIRA RANGEL, 1988; DHN, 1990; TOMAZELLI, 1993). Winds from NE to SE are formed by the South Atlantic Anticyclone which prevails during spring and summer, blowing at a speed of $2-6 \mathrm{~m} / \mathrm{s}$ (NIMER, 1989; HASENACK; FERRARO, 1989; BRAGA; KRUSCHE, 2000; TOLDO et al., 2003). The waves responsible for the erosive process on both SJN and RG estuarine margins have low height and short period (Lauro Calliari, personal communication). Barbosa (2003) verified that the southern estuarine margin in RG, without man-made protection, is eroded by waves with a height of up to $0.20 \mathrm{~m}$ and frequency of 1-5 s. Waves generated either by winds from SWNW or from NE-SE can have a maximized erosive power during the rainy winter when the high water discharge increases the estuarine water level (COSTA et al., 2003), allowing most of the wave energy reach the salt marshes. Winds also can modify the area of the salt marshes by the aerial transport of sand. Among the salt marshes in RG, unit 09 is one of the most morphodynamic in the estuary, as the result of both natural and anthropogenic processes of the last 53 years. Loss of salt marsh area was verified for the period 1947-1975, with a substantial decrease $(-1.12 \%$ per year) caused by dune migration driven by $\mathrm{NE}$ to $\mathrm{E}$ winds. Although there is strong evidence that the rising annual rainfall in southern Brazil has increased the discharge of the main tributary of the Patos Lagoon over the last 50 years (MARENGO, 2006), the results of this study did not find any change in the trend of the erosive process of the Patos Lagoon salt marshes as between the two periods of observation (1947-1975 and 1975-2000). When these periods are compared, only 9 of the 24 salt marsh units showed an increase in their erosion rate, whereas the others were stable or even decreased their erosive process. Only $0.68 \mathrm{~km}^{2}(31.2 \%$ of the total losses) of the salt marshes on the Patos Lagoon estuary has been reclaimed for urban and aquaculture purposes over the last 53 years. Urban expansion in RG during the 1950 's and 1960's was the main cause of the $49 \%$ reduction of unit 11 . The reclaiming of salt marshes took place prior to the signing of the Federal Environmental Law of 1965 (Law $N^{\circ}$ 4,771) which classified the salt marshes as areas of permanent preservation. After the approval of the RG County Regulation of Natural Spaces bill in 1986 (RG County Law $N^{\circ} 4,116$ ) urban expansion over salt marshes had stopped. Aquaculture activity (production of 
freshwater fish and shrimps) was responsible for the destruction of salt marshes $\left(0.12 \mathrm{~km}^{2}\right)$ between 1996 and 2000 owing to the illegal construction of seventeen ponds in $\mathrm{RG}\left(-0.08 \mathrm{~km}^{2}\right)(15$ ponds in unit 19 and 2 in unit 18$)$ and $\operatorname{SJN}\left(-0.04 \mathrm{~km}^{2}\right)(4$ ponds in unit 5). Recently the State Agency of Environmental Protection (FEPAM) has ruled the shrimp production in the Patos Lagoon estuary, thus reinforcing the ban on shrimp ponds over salt marshes, dunes and native forests (POERSCH et al., 2006).

Table 2. Variations of salt marsh areas (\%) (units with variation equal or above $\pm 0.08 \%$ per year) in São José do Norte and Rio Grande counties between periods 1947-1975 and 1975-2000 due to natural (Nat) and anthropogenic (Ant) causes. Total variations of area $\left(\mathrm{km}^{2}\right)$ are also shown.

\begin{tabular}{|c|c|c|c|c|c|c|c|}
\hline \multirow[t]{2}{*}{ " Counties } & \multirow{2}{*}{$\begin{array}{c}\text { Area } \\
\text { Changes }\end{array}$} & \multicolumn{3}{|c|}{$1947-1975$} & \multicolumn{3}{|c|}{$1975-2000$} \\
\hline & & Nat & Ant & Area $\left(\mathrm{km}^{2}\right)$ & Nat & Ant & Area $\left(\mathrm{km}^{2}\right)$ \\
\hline \multirow[t]{2}{*}{ SJN } & Increase & 100.0 & 0.0 & 0.04 & 100.0 & 0.0 & 0.10 \\
\hline & Loss & 100.0 & 0.0 & -0.24 & 76.5 & 23.5 & -0.17 \\
\hline \multirow[t]{2}{*}{ RG } & Increase & 66.9 & 33.1 & 0.31 & 62.9 & 37.1 & 0.30 \\
\hline & Loss & 53.8 & 46.2 & -1.23 & 86.2 & 13.8 & -0.52 \\
\hline
\end{tabular}

Table 3. Changes of estuarine margin and island areas per year (\%) (average of periods 1987-2002 and 2002-2006) in São José do Norte and Rio Grande counties estimated by satellite images. Total variations of areas $\left(\mathrm{km}^{2}\right)$ are also shown. Variations

\begin{tabular}{|c|c|c|c|}
\hline & Local & $\begin{array}{l}\text { Average variation of area per year } \\
\qquad(\%)\end{array}$ & $\begin{array}{l}\text { Total variation of area } \\
\qquad\left(\mathrm{km}^{2}\right)\end{array}$ \\
\hline \multirow{3}{*}{ SJN } & $\begin{array}{c}\text { Estuarine Margin } \\
\text { (From Primeiro Pontal to Ponta Rasa) }\end{array}$ & -0.04 & -1.03 \\
\hline & Ovos Island & -1.28 & -0.02 \\
\hline & $\begin{array}{l}\text { Arvoredo Island (Left) } \\
\text { Arvoredo Island (Right) }\end{array}$ & $\begin{array}{l}-1.62 \\
-2.49\end{array}$ & $\begin{array}{l}-0.01 \\
-0.01\end{array}$ \\
\hline \multirow{13}{*}{ Rio Grande } & $\begin{array}{c}\text { Estuarine Margin } \\
\text { (From Molhe Oeste to Pesqueiro) }\end{array}$ & 0.005 & 0.18 \\
\hline & Torotama Island & -0.05 & -0.24 \\
\hline & Carneiros Island & -0.32 & -0.02 \\
\hline & Mosquito Island ${ }^{\mathrm{a}}$ & ------ & ------- \\
\hline & Cabras Island & -0.66 & -0.02 \\
\hline & Baicurus Island & -0.82 & -0.01 \\
\hline & Zumbi Island & -0.81 & -0.005 \\
\hline & Marinheiros Island & -0.06 & -0.24 \\
\hline & Leonídeo Island & 0.06 & 0.06 \\
\hline & Cavalos Island & -1.53 & -0.09 \\
\hline & Pólvora Island & -0.64 & -0.08 \\
\hline & Pombas Island & -0.96 & -0.03 \\
\hline & Terrapleno Island & -0.04 & -0.02 \\
\hline
\end{tabular}

above $\pm 0.50 \%$ per year are highlighted with positive values in gray cells and negative values in bold.

${ }^{a}$ Mosquito Island was completed eroded before year 2000. 
Positive Effects - Two units in southern SJN (units 1 and 2) showed increases in their areas over the 53 years covered by this study because of sediment transport from the $\mathrm{W}-\mathrm{NW}$ caused by waves and winds from the south quadrant (ANTIQUEIRA; CALLIARI, 2005). The development and stabilization of unit 2 created a barrier to the southerly winds responsible for the erosion of the southern margin of unit 3. The increase of the salt marsh area in RG over 53 years $\left(+0.61 \mathrm{~km}^{2}\right)$ was due mainly to a natural process $\left(+0.40 \mathrm{~km}^{2} ; 65.6 \%\right)$ by salt marsh expansion over mud flats and grasslands (Unit $17-0.37 \mathrm{~km}^{2}$ during the whole study period and Unit $18-0.03 \mathrm{~km}^{2}$ between 1947 and 1975). The salt marshes in unit 17 are mainly vegetated nowadays by Juncus kraussii, which has replaced the grass Spartina densiflora as well as has invaded grassland areas over the last 50 years (MARANGONI, 2008). In the same period (53 years), $34.4 \%$ of the increase in the salt marsh area has been due to anthropogenic activities $\left(+0.21 \mathrm{~km}^{2}\right)$. During the 1970's, the Port Authority (SUPRG) disposed dredged sediment (about 1,000,000 $\mathrm{m}^{3}$ ) from Rio Grande Harbor on the west margin of unit 10, creating intertidal mud flats being latterly colonized by salt marsh plants. Another important increase took place during 1975-2000 in unit 9, near of the West jetties $\left(+0.05 \mathrm{~km}^{2}\right)$. This salt marsh area resulted from the trapping of sediment because of the construction of rocky groins during the 1960's and 1970's to prevent the erosive process of the margin (Former Port Authority, personal communication). This man-made barrier allowed plant colonization and the complete covering of the low and middle intertidal zones of the salt marsh in the 1980's. Since then this area has developed a considerable landscape diversity consisting nowadays of salt marshes, foredunes, stabilized dunes and grasslands occupied by at least 47 species of plant and 32 species of bird (SILVA et al., 1993; EICHENBERGER, 1999; MARANGONI, 2003).

In conclusion, the total salt marsh area of the Patos Lagoon has remained almost unchanged since 1947, however this stability conceals intense constructive and destructive processes dependent on both natural and anthropogenic origins. Basically the main losses of area have been due to estuarine hydrodynamics whereby NW-SW and NE-SE winds seem to have been responsible for erosive processes on the east (SJN) and west margins (RG), respectively. Over half a century salt marsh losses owing to anthropogenic activities have not been significant. The urban and port expansion into salt marsh areas which took place prior to the 1950's moved away from vegetated margins after this period. Moreover, traditional economic activities based on small and medium-sized farms and ranches using low production technology are not besieging local salt marshes. Future proposals for salt marsh conservation and management on the Patos Lagoon estuary should pay attention to the local hydrodynamics of the individual marsh units.

\section{ACKNOWLEDGMENTS}

This research was sponsored by the Brazilian National Research Council (CNPq), under grants $\mathrm{n}$. 141797/2004-5 (JCM) and 301763/2006-2 (CSBC).

\section{REFERENCES}

ANTIQUEIRA, J. A. F.; CALLIARI, L. J. Características sedimentares da desembocadura da Laguna dos Patos. Gravel, v. 3, p. 39-46, 2005.

BARBOSA, T. G. Variação da linha de costa na margem oeste do canal do norte, estuário da Laguna dos Patos, RS - Brasil: aspectos geo-ambientais e evolução histórica. Dissertação (Mestrado). Oceanografia Física, Química e Geológica, FURG, Rio Grande, 2003.

BRAGA, M. F. S.; KRUSCHE, N. Padrão de ventos em Rio Grande, RS, no período de 1992 a 1995. Atlântica, v. 22, p. 27-40, 2000.

CÂMARA, G.; SOUZA, R. C. M.; FREITAS, U. M.; GARRIDO, J. SPRING: Integrating remote sensing and GIS by object-oriented data modelling. Computers, Graphs, v. 20, p. 395-403, 1996.

COIMBRA, F. L.; COSTA, C. S. B. Mapeamento digital dos macrohábitats de dunas e marismas da costa do rio grande do sul através de imagens de satélite e fotografias aéreas. In: ENCONTRO NACIONAL DE GERENCIAMENTO COSTEIRO, 2006, São Vicente. Available: $<$ http://www.agenciacosteira.org.br/downloads /resumos/ResumoFrancianecorrigido.doc $>$ Accessed: 24 Nov. 2007.

COSTA, C. S. B. Tidal marsh and wetland plants. In: SEELIGER, U.; ODEBRECHT, C.; CASTELLO, J. P. (Ed.). Subtropical convergence environments. The coast and sea in the Southwestern Atlantic. Berlin: Springer-Verlag, 1997. p. 24-26.

COSTA, C. S.; MARANGONI, J. C. Impacto ambiental do asfaltamento da BR 101 sobre as marismas de São José do Norte (RS, Brasil): estado atual e efeitos potenciais. In: SIMPÓSIO DE ECOSSISTEMAS BRASILEIROS: Conservação, 5., 2000, Vitória. Anais... Vitória: ACIESP, 2000. v. 1, p. 268-291. Available: <http://www.peld.furg.br/grp/ccosta/Anais/Costa\&Mara ngoni2000.pdf>. Accessed: 14 Mar. 2007.

COSTA, C. S. B.; SEELIGER, U.; OLIVEIRA, C. P. L.; MAZO, A. M. M. Distribuição, funções e valores das marismas e pradarias submersas no Estuário da Lagoa dos Patos (RS, Brasil). Atlântica, v. 19, p. 67-85, 1997.

COSTA, C. S.; MARANGONI, J. C.; AZEVEDO, A. M. G. Plant zonation in irregularly flooded salt marshes: relative importance of stress tolerance and biological interactions. J. Ecol., v. 91, p. 951-965, 2003.

DHN - Diretoria de Hidrografia e Navegação (Marinha do Brasil). Carta Náutica n. 2112 de Rio Grande à Feitoria. 2 ed. 1990. 
EICHENBERGER，C. C. Caracterização e valorização ambiental dos sistemas de praia, dunas e marismas ao sul do molhe oeste da barra do Rio Grande - RS Monografia (Graduação). Oceanologia, FURG, Rio Grande, 1999.

HASENACK, H.; FERRARO, L. W. Considerações sobre o clima da região de Tramandaí, RS. Pesquisas, v. 22, p. 53-70, 1989.

MARANGONI, J. C. Caracterização da paisagem de uma área de preservação: Estudo de caso da lagoinha (Rio Grande, RS). Atlântica, v. 25, n. 2, p. 163-169, 2003.

MARANGONI, J. C. Subsídios para o gerenciamento das marismas no estuário da Lagoa dos Patos (RS). Tese (Doutorado). Oceanografia Biológica, FURG, Rio Grande, 2008.

MARENGO, J. A. Mudanças climáticas globais e seus efeitos sobre a biodiversidade: Caracterização do clima atual e definição das alterações climáticas para o território brasileiro ao longo do século XXI. Biodiversidade 26. Brasília: MMA. 2006. Available: $<$ http://www.mma.gov.br/index.php?ido=cont eudo.monta\&idEstrutura=14\&idConteudo=5445> . Accessed: 17 Jun. 2007.

MESQUITA, A. R. Sea-level variations along the Brazilian Coast: A short review. J. coast. Res. (SI), v. 35, p. 21 $31,2003$.

NIMER, E. Climatologia do Brasil. 2. ed. Rio de Janeiro:IBGE, 1989. 421 p.

NOGUEIRA, R.X.S; COSTA, C.S.B. Mapeamento das marismas do estuário da Lagoa dos Patos (RS) utilizando fotografias aéreas digitais $35 \mathrm{~mm}$ no modo infravermelho. In: CONGRESSO DA ASSOCIAÇÃO BRASILEIRA DE ESTUDOS DO QUARTENÁRIOABEQUA, 9., 2003 , Recife.Available:<http://www.peld.furg.br/grp/ccosta/An ais/Nogueira\&Costa2003b.PDF>. Accessed: 20 Jan. 2007.

POERSCH, L.; CAVALLI, R. O.; WASIELESKY, W.; CASTEllo, J. P.; PEIXOTO, S. R. M. Perspectivas para o desenvolvimento dos cultivos de camarões marinhos no estuário da Lagoa dos Patos, RS. Ciênc. Rural, v. 36, n. 4, p. 1337-1343, 2006.
SEELIGER, U.; COSTA, C. S. B. Human and Natural Impacts. In: SEELIGER, U.; ODEBRECHT, C.; CASTELLO, J. P. (Ed.). Subtropical convergence environments: the coast and sea in the Southwestern Atlantic. Berlim: Springer-Verlag, 1997. p. 197-203.

SEELIGER, U.; COSTA, C. S. B. Alterações de hábitats devido às atividades antrópicas na Costa Sul do Brasil. In: CLAUDINO-SALES, V. (Org.) Ecossistemas Brasileiros: manejo e conservação. Fortaleza: Expressão Gráfica e Editora, 2003. p. 237-244.

SILVA, F. D. Enchente de maio de 1941. Ministério dos Transportes - Departamento Nacional de Portos e Vias Navegáveis - Oitava Diretoria Regional, 1941.

SILVA, C. P.; PEREIRA, C. M. P.; DORNELES, L. P. P. Espécies de gramíneas e crescimento de Spartina densiflora Brong. em uma marisma da Laguna dos Patos, RS, Brasil. Cad. Pesq. Ser. Bot., Santa Cruz do Sul, v. 5, n. 1, p. 95-108, 1993.

STECH, J. L.; LORENZZETTI, J. A. The response of the south Brazil bight to the passage of wintertime cold fronts. J. geophysic. Res., v. 97, n. 6, p. 9507-9520, 1992.

TOMAZELLI, L. J. O regime de ventos e a taxa de migração das dunas eólicas costeiras do Rio Grande do Sul, Brasil. Pesquisas, v. 20, n. 1, p. 18-26, 1993.

TOLDO, E. E.; ALMEIDA, L. E. S. B.; CORRÊA, I. C. S. Forecasting shoreline changes of Lagoa dos Patos Lagoon, Brazil. J. coast. Res. (SI), v. 35, p. 43-50, 2003.

VIEIRA, E. F.; RANGEL, S. S. Planície costeira do Rio Grande do Sul: geografia física, vegetação e dinâmica sócio-demográfica. Porto Alegre: Sagra, 1988. 256 p.

(Manuscript received 19 August 2008; revised 10 March 2009; accepted 16 July 2009) 